\title{
Konflikt czy współzawodnictwo? 0 zakresie, metodach oraz skuteczności działania cyrulików i Niebieskich Uzdrowicieli w świetle polskiego piśmiennictwa mirakularnego (XVII-XVIII w.) ${ }^{2}$
}

Słowa kluczowe: księgi cudów i łask; cyrulicy; cud-kara; gradacja świętości

Księgi cudów i łask odgrywają znaczną rolę w badaniach nad dziejami kultu i ruchem pielgrzymkowym. Innymi ważnymi polami badawczymi są: historia medycyny, relacje między sacrum i profanum, postawy i oczekiwania pielgrzymów względem Niebieskich Uzdrowicieli. Między innymi do tych ostatnich obszarów nawiązuje niniejsze opracowanie, które ma charakter rekonesansu. Na jego kartach odpowiem na pytanie o obszary ludzkiej egzystencji, w który ingerowali pośredniczący w łaskach. Po tej refleksji wskażę formy kontaktu z Siłą Wyższą oraz ryty, które leżały u podstaw terapeutycznych interwen-

${ }^{1}$ Instytut Historii, Uniwersytet Adama Mickiewicza, Poznań, e-mail: greta@amu. edu.pl, ORCID: 0000-0002-7894-2589.

2 Pragnę podziękować Panu doktorowi Jakubowi Węglorzowi za celne i tym samym pomocne uwagi oraz sugestie. 
cji. W części poświęconej Niebieskim Uzdrowicielom przyjrzę się także trwałości ich pośredniczenia w łaskach: w jakich okolicznościach ono ustawało? W ramach warsztatu badawczego historyka wyzyskam metodę indukcyjną oraz obliczenia szacunkowe.

W drugiej części opracowania skoncentruję się na działaniach cyrulików i m.in. odpowiem na pytanie o zalecane przez nich kuracje, medykamenty. Nie mniej interesujący wydaje się obraz cyrulików, który utrwalono w księgach cudów i łask. Zawierał on takie elementy, jak ocena ich pracy, poglądy na temat skuteczności oraz przyczyny braku zaangażowania. Wyjaśnię też, kto był autorem tych sądów wartościujących: autorzy ksiąg, pielgrzymi, a może sami cyrulicy? Odpowiedź na to pytanie jest kluczowa, ponieważ ujawni, czy w księgach z rozmysłem deprecjonowano ziemską medycynę czy też umniejszenie jej znaczenia było ubocznym skutkiem zapisywania relacji chorych. Ta refleksja oraz wnioski z obu części posłużą nadrzędnemu celowi: udzieleniu odpowiedzi na pytanie postawione w tytule.

Podstawę źródłową opracowania stanowiły trzy opublikowane księgi związane miejscami kultu z zachodnich obszarów Rzeczypospolitej: Skarb Nieprzebrany Dobrodziejstw Boskich. Obraz Cudowny Naświętszey Panny Mariey w Opactwie Bledzewskim Rokitnickiey Jana Kazimierza Steczewicza, Cuda y Znakomite Łaski za Przyczyna Błogosławionego Bogumiła Arcy-biskupa Gnieźnieńskiego Stefana Damalewicza oraz Żywot i Cuda Wielebnego Stugi Bożego O. Bernarda $z$ Wąbrzeźna Marcina Chwaliszewskiego ${ }^{3}$. U podstaw selekcji leżała względna równowaga ilościowa. Otóż te trzy księgi zawierają porównywalną liczbę zapisek dotyczących uzdrowień (cuda Bernarda: 72,

${ }^{3}$ J.K. Steczewicz, Skarb Nieprzebrany Dobrodziejstw Boskich. Obraz Cudowny Naświętszey Panny Mariey w Opactwie Bledzewskim Rokitnickiey, Poznań 1672; S. Damalewicz, Cuda y Znakomite Łaski za Przyczyna Błogosławionego Bogumita Arcy-biskupa Gnieźnieńskiego, tłum. B. Sokołowski, Kalisz 1806; M. Chwaliszewski, Żywot i Cuda Wielebnego Stugi Bożego O. Bernarda z Wabrzeźna, Poznań 1881; jako materiał ilustracyjny wykorzystałam „Prospekt Wesoły”, w którym zebrano 447 cudów (1511-1726): Ks. Surmatowski, Prospekt Wesoły, Miłosiernych Oczu, Przenayswiętszey Maryi, Na smutne ludzkiey niedoli przypadki, z Gory S. Gostynskiey, Poznań 1726; literatura dotycząca maryjnych miejsc kultu, a także piśmiennictwa jest obszerna, a dane często rozproszone. Do kompleksowych ujęć należy: Sanktuarium rokitniańskie. Dzieje i konteksty, G. Chojnacki, A. Draguła (red.), Zielona Góra 2009; na temat piśmiennictwa staropolskiego: A. Witkowska, J. Nastalska-Wiśnicka, $\mathrm{Ku}$ ozdobie i obronie Rzeczypospolitej. Maryjne miejsca święte w drukach staropolskich, Lublin 2013; kult Bernarda i Bogumiła został omówiony głównie w publikacjach o religijnym charakterze: np. A.Z. Józefowicz, Wokót błogosławionego - świętego Bogumiła, Warszawa 2013; L. Wilczyński, Stuga Boży Bernard z Wąbrzeźna OSB: dzieje kultu, Poznań 2016. 
Konflikt czy współzawodnictwo? O zakresie, metodach oraz skuteczności...

cuda Matki Bożej: 65, cuda Bogumiła: 63) ${ }^{4}$. Dodam także, że ten materiał źródłowy narzucił zakres chronologiczny opracowania. W opowieściach de miraculis Matki Bożej Rokitniańskiej opisano zdarzenia z lat 60. i 70. XVII w., cuda Bogumiła zachowały dane od 1645 do 1748 r., natomiast księga łask Bernarda - od jego śmierci w 1603 do 1772 r. ${ }^{5}$

Aktywność świętych pośredników obejmowała wszelkie dziedziny, w których życie, zdrowie lub stateczny i spokojny byt człowieka były zagrożone. Niemniej Niebiescy Uzdrowiciele i Matka Boża pośredniczyli przede wszystkim w procesie leczenia. Jak wspominałam, w księgach cudów Bernarda, Matki Bożej Rokitniańskiej oraz arcybiskupa Bogumiła odnotowano kolejno: 72, 65 oraz 63 zdarzenia mirakularne związane z uzdrowieniem ${ }^{6}$. Jeśli dodamy do tego wsparcie udzielone matce i dziecku podczas porodu, to otrzymamy następujące wyniki: Bernard - 74, Matka Boża Rokitniańska - 72, Bogumił - 667. Do kolejnych przykładowych obszarów aktywności należały: ratunek od następstw nieszczęśliwych wypadków, wsparcie w kłopotliwych sytuacjach oraz pomoc udzielona zwierzętom gospodarskim ${ }^{8}$.

Równie istotne było rozbudzenie wiary, którą możemy uznać za warunek sine qua non cudu. $\mathrm{W}$ niektórych zapiskach podkreślono, że wotanci przyjęli wymaganą postawę, której głównymi rysami były uniżenie oraz „wielka ufność” pokładana w Niebieskich Uzdrowicielach i Opatrzności ${ }^{9}$. Z kolei relacje osób cierpiących na „chorobę kołtunową" ujawniły jeszcze jeden obszar działania, mianowicie walkę za zabobonnymi przekonaniami ${ }^{10}$. Pochodząca z księgi J.K. Ste-

${ }^{4}$ M. Chwaliszewski, dz. cyt., s. 39-45, 48-50, 51-52, 53-57, 57-58, 58-60, 61-62, 6769, 97-101, 105, 109-112, 115, 117, 120-126, 133-134; J.K. Steczewicz, dz. cyt., s. 118119, 142-178, 179-187, 188-198, 201, 204-205, 206, 263-266; S. Damalewicz, dz. cyt., s. 30-31, 39-42, 54, 55-57, 65-66, 69-70, 73-74, 76, 78-79, 84-88, 89, 92-94, 96, 97-101, 103-104, 108-110, 114-117, 118, 119-122, 123-124, 132-133, 134-140, 141-142, 143-145, 150, 152, 155, 158, 246, 248-250, 252.

${ }^{5}$ W księdze cudów Bernarda jedna zapiska pochodzi z 1849 r.

6 Patrz przyp. 3.

7 Tamże; porody: M. Chwaliszewski, dz. cyt., s. 51, 58; J.K. Steczewicz, dz. cyt., s. 207-216, 261-263; S. Damalewicz, dz. cyt., s. 88-89, 94-95, 96-97.

${ }^{8}$ Ratunek od następstw i wsparcie: np. M. Chwaliszewski, dz. cyt., s. 53, 57, 61, 99, 126-127, 140-142; pomoc zwierzętom: np. J.K. Steczewicz, dz. cyt., s. 230-236.

${ }_{9}$ Np. M. Chwaliszewski, dz. cyt., s. 39-40, 52; por. A. Witkowska, Kulty patnicze piętnastowiecznego Krakowa. Z badań nad miejska kultura religijna, Lublin 1984, s. 198.

10 Zagadnienia związane z poglądami na temat kołtuna pomijam, gdyż nie są one przedmiotem dyskursu. Warto jedynie nadmienić, że literatura narosła wokół tej problematyki jest bogata, a sam „kołtun”, ,choroba kołtunowa” były przedmiotem studiów nie tylko w kontekście medycznym, ale także kulturowym: np. D. Łukasiewicz, Warkocz znad Wisty. Pruski stereotyp brudnej Polski czy prawda historyczna?, „Medycyna Nowożytna. Studia nad Historią Medycyny” 1996, t. 2, nr 2, s. 83-104. 
czewicza relacja Andrzeja Gostkowskiego świadczyła o skutecznym pośrednictwie Matki Bożej w zwalczaniu tego zabobonu. Najpierw Andrzej został obdarzony siłą duchową niezbędną do pozbycia się kołtuna, a następnie zesłano na niego kolejne łaski. Otóż, gdy „bóle kołtunowe" ustąpiły, Andrzej stał się świadkiem triumfu Siły Wyższej nad zgubnym przesądem ${ }^{11}$.

Specyfika ksiąg cudów jako zbioru zeznań pielgrzymów, którzy doznali rozmaitych łask, sugerowałaby, że nie odnajdziemy w nich przypadków świadczących o bezradności pośredników. Pozornie nic bardziej mylnego. Sporadycznie natrafiamy na relacje, zgodnie z którymi pośrednictwo Niebieskich Uzdrowicieli miało nietrwały charakter, a jego ustanie kończyło się sytuacjami zagrażającymi zdrowiu, życiu oraz spokojnemu bytowi wotantów. Te przypadki należy tłumaczyć wyłącznie jako skutek zaniedbania ze strony wiernych. Dlaczego? Wspomniana specyfika ksiąg nie narzucała im jedynie waloru środka dowodowego, na podstawie którego stwierdzano czyjąś świętość lub cudotwórczy charakter obrazu. Księgi cudów posiadały także wymiar dydaktyczny i miały uczulać wiernych na konieczność przestrzegania zasad. Owe zasady to szczera wiara oraz konieczność wywiązania się z podjętych zobowiązań, np. ślubów, które postrzegano jako zawarcie kontraktu z Siłą Wyższą, a sam gest stanowił formę zapłaty ${ }^{12}$. Oto potrzebujący ratunku stawał się niejako usługobiorcą i przez określone gesty wotywne zyskiwał łaskę. Niedopełnienie warunków umowy niosło konsekwencje, takie jak rozmaite dolegliwości, problemy czy w skrajnych przypadkach śmierć wotanta. Zatem ta pozorna „nieefektywność” Uzdrowicieli i nagły kres łaski to nic innego, jak cud-kara, znany w piśmiennictwie mirakularnym zabieg, którego celem było pouczenie o konieczności dopełnienia ślubów ${ }^{13}$. Dodajmy,

\footnotetext{
11 J.K. Steczewicz, dz. cyt., s. 179-181.

12 Por. R.C. Finucane, Miracles and Pilgrims. Popular Beliefs in Medieval England, London 1977, s. 93-98.

${ }_{13}$ Cud-kara oraz gest wotywny były powiązane; na temat ich znaczenia, genezy: A. Witkowska, Kulty patnicze ..., dz. cyt., s. 214-215; J. Jagla, Wieczna prośba i dziękczynienie. O symbolicznych relacjach między „sacrum” $i$,profanum” $w$ przedstawieniach wotywnych z obszaru Polski Centralnej, Warszawa 2009, s. 15-44; taż, Gest wotywny. Ze starożytnych sanktuariów do chrześcijańskich świątyń i średniowiecznej ikonografii, [w:] Antyk, prawda i fatsz w średniowieczu. Materiały Seminariów Mediewistycznych im. Alicji Karłowskiej-Kamzowej, J. Kowalski, T. Ratajczak (red.), Poznań 2011, s. 259-263. Jenni Kuuliala ujawniła mechanizm cudu-kary na przykładzie łask za pośrednictwem świętej Doroty. Ustanie łaski stanowiło konsekwencję nie tylko niedotrzymania warunków umowy, ale także kwestionowania mocy świętego lub braku należnego respektu. Wskazuję na tę publikację, ponieważ mimo metryki tego zbioru wspomniany mechanizm okazał się jednorodny niezależnie od rodzaju winy wiernego, a także nie-
} 
Konflikt czy współzawodnictwo? O zakresie, metodach oraz skuteczności...

że cuda-kary były rzadkie. W księgach Bogumiła, Matki Bożej oraz Bernarda zanotowano kolejno: 3, 1, 0 takich relacji ${ }^{14}$. Co interesujące, przykłady pochodzące z pierwszej księgi świadczyły właśnie o nagłym ustaniu pośredniczenia w łasce. Dwie ze wspomnianych trzech relacji dotyczyły zaniechania pielgrzymek mieszkańców Sieradza i Łęczycy do Uniejowa, wskutek czego prezydent Sieradza musiał zmierzyć się z rozmaitymi problemami, a dziecko burmistrza Łęczycy spadło z piętra. Z drugiej zapiski wynikało, że dziewczynka została w sposób cudowny ocalona, ponieważ w pore została złapana. W obu przypadkach napomnienia poskutkowały, gdyż dopełniono obowiązku peregrynacji ${ }^{15}$. Z kolei w relacjach de miraculis Matki Bożej chodziło o trudny poród. Małżonka Aleksandra Koszuckiego „cięszko y niebespiecznie choruiąca”, nie mogła urodzić dziecka. Do nadprzyrodzonej interwencji doszło po ofiarowaniu i obietnicy pielgrzymki. Ponieważ kobieta zwlekała z dopełnieniem ślubu i przedłożyła wizytę u ojca nad wspomniany obowiązek, podczas pisania listu „ciemność na oczy iey taka uderzyła, że mało co, albo nic niewidziała, y piórko iey z ręki wypadło" 16 .

Z kolei śmierć odbiorcy łaski jako kara stanowiła ekstremum. Należy przypuszczać, że ta forma wymierzenia sprawiedliwości stanowiła konsekwencję zaistnienia dodatkowych okoliczności, które obciążały winnego zaniedbania. Aby w pełni zobrazować ten mechanizm, sięgnę do materiału pomocniczego, ponieważ w omawianych trzech księgach brak odpowiedniego przykładu. W Prospekcie Wesołym Matki Bożej Świętogórskiej opisano przypadek Grzegorza, który nadużywał alkoholu. Ta skłonność skutecznie zniechęciła go do złożenia ofiary dziękczynnej za uzdrowienie. Grzegorz odpowiadał osobom napominającym go: „za cożbym pił”. Zlekceważenie umowy poskutkowało najpierw nawrotem choroby, a następnie śmiercią: młodzieniec zmarł trzeciego dnia bez sakramentów (1676-1677 r.) ${ }^{17}$. Przypadek Grzegorza był znamienny. Pokazał on, że śmierć jako kara za złamanie ślubu nie tyle dotyczyła osób, które zaniechały obowiązku z powodu zwykłego niedbalstwa, ile sytuacji, w których u podstaw braku dzia-

zmienny w kolejnych stuleciach: J. Kuuliala, Disability and Religious Practices in Late Medieval Prussia: Infirmity and the Miraculous in the Canonization Process of St. Dorothea of Montau (1404-1406), [w:] Lived Religion and the Long Reformation in Northern Europe c. 1300-1700, S. Katajala-Peltomaa, R.M. Toivo (red.), Boston 2016, s. 64-71.

${ }^{14}$ S. Damalewicz, dz. cyt., s. 104-105, 124-127, 145-146; J.K. Steczewicz, dz. cyt., s. 261-263.

${ }^{15}$ S. Damalewicz, dz. cyt., s. 124-127, 145-146.

16 J.K. Steczewicz, dz. cyt., s. 261-263.

17 Ks. Surmatowski, dz. cyt., s. 18. 
łań leżały grzechy ciężkie. W wypadku młodzieńca Grzegorza były to nieumiarkowanie w spożywaniu alkoholu oraz swoiste skąpstwo, czyli pożałowanie pieniędzy na cel niezwiązany $\mathrm{z}$ alkoholem ${ }^{18}$.

Kolejny równie unikatowy przypadek, w którym Niebiescy Uzdrowiciele pozornie zawodzili jako pośrednicy, był związany z gradacją świętości (cudowności). Niekiedy w księgach wspominano o bezskutecznej pielgrzymce wotantów do innych sanktuariów oraz o nagłym uzdrowieniu przed obrazem lub grobem kandydata na świętego, którego dotyczyły zeznania. Gradacja świętości (cudowności) miała przede wszystkim wymiar propagandowy i poza pracami komisji służyła rozsławieniu imienia postaci otoczonych kultem ${ }^{19}$. W trzech wspomnianych księgach łask gradację odnajdujemy jedynie u Bernarda. Otóż Jan Łabęcki zmagający się z liszajem najpierw oddał się pod opiekę wspomnianego Bernarda, a uzdrowiony został po pielgrzymce przed obraz Matki Bożej Boreckiej ${ }^{20}$. W podanym przykładzie uderzyło odmienne zastosowanie wspomnianego mechanizmu gradacji. $\mathrm{Z}$ czym powinniśmy łączyć tę zaskakującą nieskuteczność Bernarda przy jednoczesnym efektywnym pośrednictwie Matki Bożej? Sądzę, że Bernard oraz cały konwent $w$ ten sposób składał hołd postaci wyższej rangi, jaką była Pani Borecka na Zdzieżu. Ponadto wspomniany Bernard był dopiero kandydatem na świętego.

Księgi łask, w tym świadectwa cudów-kar, były przepełnione nawiązaniami do symboliki biblijnej, które wzmacniały przekaz. Przypomnijmy: wspomniany młodzieniec Grzegorz umarł trzeciego dnia ${ }^{21}$. Dodam, że we wspomnianych trzech księgach cudów odnajdujemy analogiczne odniesienia. W cudach za pośrednictwem Matki Bożej Rokitniańskiej opisano przypadek prawie trzyletniej Katarzyny, która chorowała trzy tygodnie, a uzdrowienie nastąpiło po odmówieniu trzech „Pozdrowień Anielskich”22. Z kolei Jan Świejkowski miał trudności w samodzielnym poruszaniu. Terapeutyczną interwencję wymusiła pielgrzymka do Dobrowa oraz trzykrotne oprowadzenie mężczyzny wokół kaplicy i obmycie nóg wodą ze studzienki ${ }^{23}$. Dodajmy, że motyw cudotwórczego działania wody stanowił nawiązanie do sło-

${ }_{18}$ Ten mechanizm został opisany w literaturze przedmiotu, por. E. Wheatley, Stumbling Blokcs Before the Blind. Medieval Constructions of a Disability, Ann Arbor 2010, s. 179.

${ }^{19}$ Np. Ks. Surmatowski, dz. cyt., s. 89, 121.

${ }^{20}$ M. Chwaliszewski, dz. cyt., s. 52.

${ }^{21}$ Ks. Surmatowski, dz. cyt., s. 18.

22 J.K. Steczewicz, dz. cyt., s. 146.

23 S. Damalewicz, dz. cyt., s. 150. 
Konflikt czy współzawodnictwo? O zakresie, metodach oraz skuteczności...

wiańskich wierzeń pogańskich, zgodnie z którymi rozmaite źródełka i strumienie były miejscem kultu. Woda miała posiadać cudowne właściwości i oczyszczała ${ }^{24}$. Z kolei cyfra trzy oznaczała pełnię (Trójca Święta), doskonałość ${ }^{25}$. Ponadto św. Piotr trzykrotnie zaparł się Chrystusa przed jego męką (J 18, 15-27) ${ }^{26}$. W opisanych przypadkach stanowiła zapowiedź cudu oraz nadawała mu nieodwołalny charakter. Jednocześnie ilustrowała jego komplementarność. Dla odmiany w opowieści o Grzegorzu śmierć trzeciego dnia należy interpretować jako nieodwołalność kary oraz napomnienie adresowane do odbiorców, aby byli pewni, jakie są nieuchronne konsekwencje zaniechania.

Dopełnienie ślubów skutkowało uzdrowieniem. Przykładowo, z ksiąg cudów i łask wynikało, że niektórzy chorzy oraz osoby dotknięte kalectwem mogły spodziewać się natychmiastowego ustąpienia objawów chorobowych. Czy odpowiedź na pytanie, od jakich czynników natychmiastowe uzdrowienie było uzależnione, jest możliwa? Najpierw jednak oszacujmy, jak liczne były doniesienia o nagłym ustąpieniu objawów. Koncentracja na świadectwach, w których expressis verbis poinformowano o natychmiastowym powrocie do pełni sił, ujawniła, że Matka Boża Rokitniańska, Bogumił oraz Bernard nie byli tak samo skuteczni. W pierwszej księdze zanotowano 40 natychmiastowych uzdrowień na 65 zdarzeń mirakularnych związanych z chorobą $(61,5 \%)^{27}$. W przypadku Bogumiła mówimy o 27 analogicznych relacjach (na 63, co daje 42,8\%), a w wypadku Bernarda o 19 świadectwach (na 72, co daje $26,4 \%)^{28}$. Te dane pokazały skuteczność pośrednictwa Niebieskich Uzdrowicieli, albowiem ich interwencje przynosiły natychmiastowy efekt średnio w 44,9\% przypadków. W tym szacunkowym zestawieniu uderza także wynik, który zaobserwowałam w odniesieniu do Matki Bożej (61,5\%). Sądzę, że ten wysoki wskaźnik ponownie należy tłumaczyć wyjątkowym statusem

${ }^{24}$ K. Moszyński, Kultura ludowa Stowian, t. 2, cz. 1, Warszawa 1967, s. 506-510; A. Gieysztor, Mitologia Słowian, wstęp K. Modzelewski, posł. L.P. Słupecki, oprac. A. Pieniądz, Warszawa 2006, s. 216-217, 257-259.

${ }^{25}$ V. Hopper, Medieval Number Symbolism. Its Sources, Meaning, and Influence on Thought and Expression, New York 2000, s. 107.

${ }_{26}$ D. Forstner, Świat symboliki chrześcijańskiej, tłum. i oprac. W. Zakrzewska, P. Pachciarek, R. Turzyński, Warszawa 1990, s. 43-44.

27 J.K. Steczewicz, dz. cyt., s. 118-119, 143-144, 144-155, 159-160, 163, 164-170, 172-174, 175-186, 188-192, 194-195, 197-198, 201, 263-266.

${ }^{28}$ S. Damalewicz, dz. cyt., s. 39-42, 54, 73-74, 86-89, 97-101, 103-104, 109-110, 116, 118, 120-122, 134-135, 137-139, 141, 143-144, 150, 155; M. Chwaliszewski, dz. cyt., s. 39-40, 48-49, 53-62, 68, 98, 100-101, 105, 111-112, 121-122, 125-126. 
Maryi jako Bożej Rodzicielki, która cieszyła się szczególnymi względami Opatrzności ${ }^{29}$.

Niekiedy łaski miały nie tyle nagły, ile spektakularny charakter, o czym świadczyła relacja Wojciecha Marklewicza. W jego przypadku choroba miała zaawansowany charakter i mężczyzna „na nogi żadną miarą postąpić nie mógł"30. Wojciech został przywieziony do świętego miejsca, a do grobu Bogumiła „na kulach przyczołgał się”31. Oprócz pielgrzymki skuteczny okazał się bezpośredni kontakt z sacrum: pocałunek złożony na skrzyni z relikwiami Bogumiła, po którym Wojciech odrzucił kule i odtąd poruszał się samodzielnie ${ }^{32}$. Ten widowiskowy charakter uzdrowienia: odzyskanie pełnej władzy w nogach $\mathrm{w}$ obecności innych wiernych był istotnym elementem opowieści de miraculis. Umacniał on świadków w przekonaniu o cudotwórczej mocy grobu, relikwii lub pośredniczeniu w łaskach kandydata na świętego ${ }^{33}$. Czy widowiskowość cudu oraz bezpośredni kontakt z sacrum były gwarantami natychmiastowego efektu? Niestety nie. Co prawda, w przypadku wielu osób, które z powodu rozmaitych chorób miały problemy z poruszaniem i które dodatkowo pielgrzymowały do sanktuariów, odnotowano natychmiastowe odzyskanie władzy w nogach. Świadczyły o tym niektóre relacje wotantów uciekających się do pośrednictwa Matki Bożej Rokitniańskiej i Bogumiła. W pierwszej księdze opisano np. jeden przypadek osoby natychmiast uzdrowionej $\mathrm{w}$ obszarze sacrum ${ }^{34}$. Analogicznie w świadectwach związanych z Bogumiłem przedstawiono trzy relacje należące do tej grupy i dwie dotyczące osób stopniowo odzyskujących władzę w nogach $\mathrm{w}$ domu ${ }^{35}$. Ten obraz zaburzyły świadectwa de miraculis Bernarda. W kilku zeznaniach doniesiono o uzdrowieniu $\mathrm{w}$ domu chorego: trzy miały

${ }^{29}$ Por. J. Jagla, Wieczna prośba..., dz. cyt., s. 38-39.

${ }^{30}$ Np. S. Damalewicz, dz. cyt., s. 74.

31 Tamże.

${ }^{32}$ Tamże; na temat genezy wiary w moc grobu: A. Witkowska, „Peregrinatio religio$s a " w$ średniowiecznej Europie, [w:] Peregrinationes. Pielgrzymki w kulturze dawnej Europy, H. Manikowska, H. Zaremska (red.), Warszawa 1995, s. 13.

33 A. Witkowska, Kulty patnicze..., dz. cyt., s. 218-226; przypadek Wojciecha Marklewicza koreluje z odpowiedziami na pytanie, czym w kontekście terapeutycznych interwencji były relikwie? Według Petera Dinzelbachera w relikwiach była skumulowana siła świętych pośredników. Dodatkowo relikwie emanowały tą mocą m.in. na potrzebujących pielgrzymów. Tenże, Die „Realpräsenz” der Heiligen in ihren Reliquiaren und Gräbern nach mittelalterlichen Quellen, [w:] Heiligenverehrungin Geschichte und Gegenwart, P. Dinzelbacher, D.R. Bauer (red.), Ostfildern 1990, s. 158.

${ }^{34}$ Np. J.K. Steczewicz, dz. cyt., s. 185-186; w księdze przedstawiono też świadectwo osoby, którą zaniesiono przed obraz, aczkolwiek nie podano, jak szybko doszło do terapeutycznej interwencji, tamże, s. 151.

${ }_{35}$ Np. S. Damalewicz, dz. cyt., s. 55-57, 74, 109-110, 140, 150. 
Konflikt czy współzawodnictwo? O zakresie, metodach oraz skuteczności...

natychmiastowy charakter, a w przypadku dwóch osób rekonwalescencja trwała dłużej ${ }^{36}$.

Inną formą kontaktu z sacrum były objawienia senne lub na jawie, które towarzyszyły procesowi uzdrowienia ${ }^{37}$. Jak ujawniły księgi cudów Matki Bożej, Bogumiła oraz Bernarda, schemat snu leczącego i widzenia na jawie był w miarę jednorodny: chory zapadał w drzemkę albo był przytomny, doświadczał wizji cudotwórczego obrazu lub postaci kandydata na świętego czy Matki Bożej, z którą nawiązał kontakt werbalny i przez dotyk, a następnie budził się (sen leczący) i zdrowiał. Sen leczący czasami poprzedzała modlitwa chorego ${ }^{38}$. Ponownie zapytajmy, czy tym razem sen leczący gwarantował natychmiastowe uzdrowienie? Odpowiedź znowu będzie przecząca. Jak pokazał przykład Ewy Siwochowej, widzenie Bernarda podczas snu zaowocowało jedynie poprawą samopoczucia. Pełne uzdrowienie nastąpiło dopiero po modlitwie ${ }^{39}$.

Reasumując, w ramach tego rekonesansu możemy ostrożnie założyć, że nagłe uzdrowienie nie było skutkiem wspomnianych rytów terapeutycznych (kontaktu z sacrum na jawie lub we śnie). Niemniej sformułowanie jednoznacznego wniosku wymagałoby studiów szczegółowych, dla których podstawą byłby odpowiednio obfity zasób ksiąg łask. Otwarta pozostaje także kwestia korelacji między uzdrowieniami osób, które nie mogły się poruszać, a pielgrzymką lub obietnicą peregrynacji jako gestami proszalnymi. Co prawda, wiele świadectw sugerowało taki związek, niemniej powtórzę, że jednoznaczną konkluzję powinny poprzedzić szeroko zakrojone badania ${ }^{40}$.

Świadectwa odnotowane w księgach łask pokazywały, że interwencja Niebieskich Uzdrowicieli kończyła się powrotem do zdrowia, ale czy cudowne uzdrowienia miały trwały charakter? W przypadku części z nich odpowiedź powinna być twierdząca. Ten ostrożny wniosek możemy wysnuć na podstawie dwóch grup przesłanek: z jednej strony w księgach niekiedy wyraźnie formułowano opinię o trwałym charakterze cudu, z drugiej natomiast świadectwo dawali sami wotanci, którzy składali zeznanie wiele lat po doznanej łasce. Relacji związanych

${ }^{36}$ M. Chwaliszewski, dz. cyt., s. 49-50, 55, 100-101, 111-112, 169.

${ }^{37} \mathrm{O}$ śnie leczącym, wizjach oraz ich roli w procesie uzdrowienia: R.C. Finucane, dz. cyt., s. 67-68; por. A. Witkowska, Kulty patnicze..., dz. cyt., s. 222.

38 J.K. Steczewicz, dz. cyt., s. 182-184, 198-200; S. Damalewicz, dz. cyt., s. 92-94, 120-121, 135-136; M. Chwaliszewski, dz. cyt., s. 42-43; por. A. Witkowska, Kulty patnicze..., dz. cyt., s. 222.

${ }^{39}$ M. Chwaliszewski, dz. cyt., s. 42-43.

${ }^{40}$ Np. J.K. Steczewicz, dz. cyt., s. 185-186, 151; S. Damalewicz, dz. cyt., s. 55-57; M. Chwaliszewski, dz. cyt., s. 55. 
z tą pierwszą grupą było niewiele. W księdze cudów i łask Bernarda czterokrotnie doniesiono o całkowitym, a także bezpowrotnym ustąpieniu objawów chorobowych, w opowieściach de miraculis Bogumiła raz, natomiast w cudach Matki Bożej Rokitniańskiej nie wspomniano o tym w ogóle ${ }^{41}$. Przykładowo, wspomniany Jan Świejkowski cierpiał na „ból nieznośny [...] w nogach”, a ojciec Leonard Kretuński z klasztoru lubińskiego zmagał się z bólem zębów i oczu. Przypomnijmy, w pierwszym przypadku kontakt z sacrum zaowocował trwałą łaską ${ }^{42}$. Z kolei w drugim po ofiarowaniu srebrnej tabliczki wotywnej nie tyle dolegliwości ustąpiły, ile Kretuński „odtąd żadnego zgoła bólu w oczach i zębach nie czuje" 43 .

Trwałość doznanej łaski sugerowały także zapiski, w których utrwalono zdarzenia mirakularne sprzed kilku, kilkunastu lub kilkudziesięciu lat. W księdze cudów Bogumiła część świadectw zanotowano w 1748 r. I tak, Agnieszka Bezan została uzdrowiona z ciężkiej choroby, która nie dawała „nadziei dalszego życia”, dekadę przed spisaniem okoliczności cudu ${ }^{44}$. Z kolei 15 lat dzieliło złożenie zeznania od łaski uzdrowienia, która stała się udziałem Jadwigi, siostry księdza Kazimierza Teofila Białeckiego. Jak odnotowano, w przypadku Jadwigi, wtedy dziesięcioletniej dziewczynki, „głowa, nogi, ręce w kupie były" ${ }^{45}$. Za to wspomniany Jan Świejkowski został uleczony w 1728 r., a świadectwo dał 20 lat później ${ }^{46}$.

W nowożytnych księgach łask niekiedy pojawiają się odniesienia do ziemskiej medycyny. Czemu służyły? Czy miały wymiar dokumentalny czy propagandowy? Najpierw sprawdźmy, jakie informacje odnotowano. Analiza ksiąg pozwala na oszacowanie liczby cyrulików i akuszerek ${ }^{47}$. Najmniejszy udział przedstawicieli tej pierwszej grupy zanotowano w księdze łask Bernarda. W grupie 74 zdarzeń mirakularnych, w których opisano objawy chorobowe oraz doniesiono o akcjach porodowych, cyrulików wymieniono dwa razy, natomiast o samych

${ }^{41}$ M. Chwaliszewski, dz. cyt., s. 57-58, 59, 110; S. Damalewicz, dz. cyt., s. 150.

${ }^{42}$ S. Damalewicz, dz. cyt., s. 150.

${ }^{43}$ M. Chwaliszewski, dz. cyt., s. 110; na temat historii i rozmaitych interpretacji wotów srebrnych: J. Olędzki, Wota srebrne, „Polska Sztuka Ludowa” 1967, R. 21, nr 2, s. 67-92; J. Jagla, Wieczna prośba..., dz. cyt., s. 65-66.

${ }^{44}$ S. Damalewicz, dz. cyt., s. 119-120.

${ }^{45}$ Tamże, s. 55-56.

46 Tamże, s. 150.

${ }^{47} \mathrm{O}$ medykach, cyrulikach, akuszerkach w okresie nowożytnym np.: J. Kowalska, Personel medyczny miast królewskich Rzeczypospolitej w latach 1773-1792, [w:] Wśród córek Eskulapa. Szkice z dziejów medycyny i higieny w Rzeczypospolitej XVI-XVIII wieku, A. Karpiński (red.), cz. 2, Warszawa 2015, s. 315-368. 
Konflikt czy współzawodnictwo? O zakresie, metodach oraz skuteczności...

kuracjach wspomniano trzykrotnie $(6,8 \%)^{48}$. Dla odmiany w zbiorze świadectw pielgrzymujących przed obraz Matki Bożej Rokitniańskiej przedstawiono osiem takich przypadków na $72(11,1 \%)$. W tej grupie sześć razy wyraźnie wskazano na udział cyrulików oraz zabiegi przez nich zalecane. W pozostałych dwóch relacjach odniesiono się ogólnie do stosowanych kuracji ${ }^{49}$. Dodajmy, że w tym zbiorze świadectw opisano też działalność akuszerek. Obecność „bab”, określonych jako „wiadome tych przypadkow białegłowy”, wzmiankowano cztery razy ${ }^{50}$. Za to w księdze cudów Bogumiła liczba świadectw, w których przedstawiono zaangażowanie cyrulików oraz medyczne kuracje, była spora. Na 66 przypadków w 17 zanotowano różnego rodzaju interwencje oraz ogólnie odniesiono się do zastosowanych terapii (25,8\%). Nadmienię, że w tej grupie obecność cyrulików stwierdzono dziewięć razy ${ }^{51}$.

Specyfika tego rodzaju piśmiennictwa niekiedy wymagała podkreślenia braku zaangażowania cyrulików. Istotne było wskazanie, że remisja choroby nastąpiła wyłącznie dzięki nadprzyrodzonej interwencji. Takie podejście wynikało z postrzegania cudu jako dowodu na świętość postaci lub cudowność artefaktu ${ }^{52}$. Dodatkowo, dzięki temu samo zdarzenie mirakularne stawało się wiarygodne. Informacje o nieangażowaniu cyrulików oraz niezażywaniu leków spotykamy w księdze cudów Matki Bożej Rokitniańskiej, natomiast brak ich w żywotach Bogumiła oraz Bernarda. We wspomnianej księdze sześciokrotnie podkreślono, że chorzy nie korzystali z rad cyrulików oraz nie zażywali leków („żadnego lekarstwa ani Cyrulika niezażywaiąc” lub „,̇adnego niezażywaiąc lekarstwa”) ${ }^{53}$.

W księgach najczęściej podawano ogólnikowo, że zaordynowano jakieś kuracje, natomiast sporadycznie precyzowano rodzaj terapii. Ponownie wyjątkowe pod tym względem okazuje się dzieło J.K. Steczewicza, w którym pięć razy odnotowano puszczanie krwi ${ }^{54}$. Tylko

${ }^{48}$ M. Chwaliszewski, dz. cyt., s. 40, 42-43, 49-50, 68-69, 101.

49 J.K. Steczewicz, dz. cyt., s. 118-119, 142-143, 157-159, 168-169, 185-186, 189190, 193-194.

50 Tamże, s. 209-216; por. B. Zaborowska, Pomoc przy porodach w Rzeczypospolitej $w$ epoce nowożytnej w świetle zielników i poradników medycznych, [w:] Wśród córek Eskulapa. Szkice z dziejów medycyny i higieny w Rzeczypospolitej XVI-XVIII wieku, A. Karpiński (red.), Warszawa 2009, s. 290-291; J. Kowalska, dz. cyt., s. 339-350.

51 S. Damalewicz, dz. cyt., s. 39-41, 54, 55-57, 65-66, 76, 78-79, 84-85, 88, 92-94, 99-100, 103-104, 122, 135-136, 138-139, 140, 144-145, 152.

52 Por. J. Duffin, Medical Miracles. Doctors, Saints and Healing in the Modern World, Oxford-New York 2009, s. 15-17.

53 J.K. Steczewicz, dz. cyt., s. 143-144, 159, 162-163, 164-165, 174.

54 Tamże, s. 118-119, 157-159, 189-190, 198-200; o historii flebotomii w okresie nowożytnym, a ponadto o zasadach, procedurach, poglądach na jej temat: A. Wieniawska, 
w jednym przypadku wspomniano, że mężczyźnie z gorączką i katarem puszczono krew spod języka. Dodajmy, że po tym zabiegu pacjent poczuł się gorzej5s. Pogorszenie stanu obserwujemy także u pewnej ciężko chorej kobiety. Jak podał autor, „iey wiele krwie Cyrulik upuścił, bo we cztery godziny po krwi, który kaduk po dziesięć razy się wracał y rzucał ią wysoko w gorę"56.

Pozostałe zabiegi z obszaru ziemskiej medycyny to np. wspomniane w katalogu łask Matki Bożej Rokitniańskiej bańki, które miały złagodzić bóle w boku i lewej ręce, czy jakieś niezidentyfikowane kuracje na oczy, które wzmiankowano w księdze Bogumiła ${ }^{57}$. Tę ostatnią kwestię być może rozświetla Prospekt Wesoły Matki Bożej Świętogórskiej. Podano w nim, że córka garncarza z Mosiny stosowała na oczy wód$\mathrm{ki}^{58}$. W omawianym okresie $\mathrm{z}$ wódek sporządzano nie tylko mikstury czy nasączano nimi okłady, ale także preparowano krople do oczu i być może to je zalecono w tych przypadkach ${ }^{59}$.

W księdze łask Matki Bożej Rokitniańskiej zanotowano także obecność „bab”, o czym wspomniałam. W dwóch relacjach ogólnie podano, że „wiadome tych przypadkow białegłowy” zareagowały, ponieważ ułożenie dziecka podczas porodu było nieprawidłowe ${ }^{60}$. Procedur nie omówiono także w pozostałych dwóch przypadkach. Dodam, że chodziło w nich o pomoc „bab” podczas martwego porodu oraz o trudny poród bliźniąt ${ }^{61}$.

W księgach cudów odnajdujemy ocenę aktywności cyrulików. Przede wszystkim sam fakt odnotowania ucieczki chorych i cierpią-

Choroby układu oddechowego w polskich osiemnastowiecznych poradnikach medycznych. Diagnozowanie, przebieg i leczenie, [w:] Wśród córek Eskulapa. Szkice z dziejów medycyny i higieny w Rzeczypospolitej XVI-XVIII wieku, A. Karpiński (red.), Warszawa 2009, s. 265-268; J. Węglorz, Zdrowie, choroba i lecznictwo w społeczeństwie Rzeczypospolitej XVI-XVIII wieku, Toruń 2015, s. 135-179.

${ }_{55}$ J.K. Steczewicz, dz. cyt., s. 118-119.

56 Tamże, s. 189-190.

57 Tamże, s. 193-194; S. Damalewicz, dz. cyt., s. 103-104; o stosowaniu baniek: J. Węglorz, dz. cyt., s. 140-141.

${ }_{58}$ Ks. Surmatowski, dz. cyt., s. 23.

${ }_{59}$ A. Klonder, Napoje fermentacyjne w Prusach Królewskich w XVI-XVII wieku. Produkcja - import - konsumpcja, Wrocław 1989, s. 125; o leczniczych wódkach i ich zastosowaniu: J. Wegglorz, dz. cyt., s. 206-207.

${ }^{60}$ J.K. Steczewicz, dz. cyt., 209-210, 212-213.

${ }^{61}$ Tamże, s. 210-212, 214-216; na temat zalecanych w takich okolicznościach procedur: B. Zaborowska, dz. cyt., s. 301-312; o działalności „bab”: J. Zagożdżon, Praktyki medyczne $w$ traktacie Pseudo-Alberta Wielkiego „O sekretach białogłowskich, mocy ziót, kamieni i zwierzat osobliwych" (z 1695 roku), [w:] Wokót choroby, medycyny i praktyk leczniczych. Teorie - konteksty - interpretacje, K. Łeńska-Bąk, M. Sztandara (red.), Opole 2009, s. 117. 
Konflikt czy współzawodnictwo? O zakresie, metodach oraz skuteczności...

cych pod opiekę Opatrzności po uprzednim stosowaniu kuracji sugerował opinię na temat ich efektywności. $\mathrm{Z}$ kolei $\mathrm{w}$ wielu zapiskach podano, że cyrulicy formułowali sądy na temat własnej bezradności i przyczyn braku zaangażowania. Mowa tu o relacjach, w których podkreślano ich rezygnację z kontynuowania kuracji. W taki sposób postąpił pewien cyrulik, który tłumaczył własną postawę tym, że jego pacjent „naturalnym sposobem żyć nigdy nie może" ${ }^{2}$. Podobnie postąpiły osoby kurujące panią Zamojską. W tej samej księdze czytamy, że padło analogiczne usprawiedliwienie: „wszyscy Doktorowie [...] konkludowali, iż naturalnym żyć nie może [...] sposobem”63.

Wśród części pielgrzymów panowało przekonanie, że do cyrulików w ogóle nie należy się zwracać, ponieważ ich zaangażowanie nie przyniesie oczekiwanych skutków ${ }^{64}$. Przykładowo, pani Korzeniewska była pewna, że jej choremu dziecku cyrulicy ,żadnego ratunku ani pomocy dać nie mogli" ${ }^{65}$. Dodam, że sporadycznie pielgrzymi byli utrzymywani w takim przeświadczeniu przez duchownych z sanktuariów. I tak, w przypadku pewnej dziewczynki, która ciężko zachorowała, to ksiądz prognozował możliwość wyleczenia. Orzekł on, że dziewczynka była „niepodobna śrzodkami doczesnymi do uleczenia” ${ }^{66}$.

Jak zatem powinna brzmieć odpowiedź na pytanie postawione w tytule? Uważam, że nie możemy mówić ani o konflikcie, ani o rywalizacji. Niebiescy Uzdrowiciele byli bardzo skuteczni w pośredniczeniu, ale to nie dziwi z uwagi na wspomniany charakter ksiąg (zeznania świadków doznanych łask). Tego obrazu nie zmienił ani cud-kara, ani gradacja świętości (cudowności) jako zabiegi mające przede wszystkim pouczać wotantów oraz rozsławić ośrodek kultu. Cyrulicy przedstawieni na tle Niebieskich Uzdrowicieli byli wprawdzie deprecjonowani, ale autorami tych sądów wartościujących okazali się najczęściej ich pacjenci oraz oni sami. Księgi cudów miały charakter dokumentalny, w związku z czym te opinie zostały jedynie odnotowane przez

${ }^{62}$ S. Damalewicz, dz. cyt., s. 31-34; odstąpienie od pacjenta było często związane $\mathrm{z}$ lękiem przed utratą dobrego imienia w przypadku niepowodzenia terapii, J. Węglorz, dz. cyt., s. 231-233, 243-245.

${ }^{63}$ S. Damalewicz, dz. cyt., s. 65-66.

${ }^{64}$ Takie stanowisko korespondowało z niektórymi ogólnymi poglądami na kompetencje cyrulików, lekarzy, szerzej: J. Węglorz, dz. cyt., s. 222-228; wspomniane sądy były ponadczasowe i pojawiły się nie tylko $\mathrm{w}$ księgach z polskiego obszaru, patrz: C. Krötzl, Saints, Healing and Communities in the Later Middle Ages: On Roles and Perceptions, [w:] Infirmity in Antiquity and the Middle Ages. Social and Cultural Approches to Health, Weakness and Care, C. Krötzl, K. Mustakallio, J. Kuuliala (red.), London 2016, s. 260.

${ }^{65}$ J.K. Steczewicz, dz. cyt., s. 153-154.

${ }^{66}$ Tamże, s. 154-155. 
autorów - nie mogło być inaczej. Dodam, że wyłaniająca się z materiału źródłowego bezradność cyrulików miała, co prawda, wymiar propagandowy, ponieważ kolidowała z obrazem Opatrzności, która za pośrednictwem Niebieskich Uzdrowicieli leczyła z każdej choroby. Niemniej istotne było pouczenie wiernych nie o zawodności ziemskiej medycyny, lecz o tym, że Siła Wyższa ofiaruje pomoc w każdej trudnej sytuacji.

\section{Summary \\ Conflict or Competition? On the Scope, Methods and Effectiveness of Medics and Heavenly Healers in Light of the Polish Miracle Literature (of the $17^{\text {th }}-18^{\text {th }} \mathrm{c}$.)}

The study is based on three sources which are the books of miracles of Bernard of Wąbrzeźno, archbishop Bogumit, and the Blessed Virgin Mary of Rokitno. The analysis revealed that the aforementioned books of miracles were not an arena of conflict. The Heavenly Healers in the books proved to be almost absolutely effective - this is a matter of course due to the specific nature of the books which are composed of certified miracles. The recorded helplessness of barber surgeons as well as ineffectiveness of recommended treatments served not so much to show intentional depreciation of this group but rather to indicate the Providence, which offered its help in every helpless situation.

Keywords: books of miracles; medics; punishment miracles; gradations of holiness 